Ясненко Мария Михайловна старший преподаватель

ФГБОУ ВО «Московский государственный университет им. М.В. Ломоносова» г. Москва

DOI $10.21661 / r-464838$

\title{
ОСОБЕННОСТИ ОБУЧЕНИЯ ИНТРОВЕРТОВ
}

Аннотация: в статье рассматриваются особенности характера интровертов, которые могут оказаться ключевыми при выборе того или иного подхода в обучении. Особое внимание уделяется возможностям рассмотрения главных черт интровертов как их положительных сторон, способствующих более качественному получению знаний.

Ключевье слова: интроверт, образование, обучение, личность, психика, знания.

Когда мы сталкиваемся с понятием «интроверт», нам сразу представляется необщительный, замкнутый человек, с которым невероятно тяжело разговаривать и в обществе которого чувствуешь себя крайне неуютно. Интровертность раньше считалась скорее негативной характеристикой человека. Подразумевалась слабая личность, неспособная как-то проявить себя, не имеющая никаких талантов и способностей. Но постепенно это понятие становилось широко употребляемым, популярным. Часто мы сами относим себя к интровертивным личностям, оправдывая тем самым наше нежелание много и активно говорить, долгое время находиться среди большого количества людей, увлеченно поддерживать беседу и мгновенно реагировать на происходящее вокруг нас. Мы отгораживаемся от окружающего мира, мы отказываемся от новых знакомств, мы предпочитаем оставаться наедине с собой, объясняя это в первую очередь самим себе тем, что мы интроверты, что у нас такой склад личности.

Если выбор того или иного места работы, создание семьи или проживание в одиночестве, проведение свободного времени в шумной компании или дома 
в тишине полностью зависит от каждого конкретного человека, то проблема получения образования так или иначе встает перед каждым человеком. Кроме того, этот процесс занимает много времени, забирает много сил и энергии. И тут возникает вопрос: как же интровертам учиться и как их обучать, чтобы добиться максимально хорошего результата, не влияя негативно на психику ученика или студента.

Здесь стоит заметить, что радикальное деление всех людей на интровертов и экстравертов не совсем справедливо. Как правило, в каждом из нас есть черты, присущие как интровертивным, так и экстравертивным личностям. Но, действительно, существуют люди, которые в большей степени тяготеют к тому, чтобы быть названными интровертами. В связи с этим появляется вопрос, нуждаются ли такие люди в особенном отношении со стороны окружающих, в том числе, педагогов.

Понятие «интроверсия» было введено в научный обиход Карлом Густавом Юнгом в начале 1910-х годов. Согласно его теории, интроверту свойственны следующие черты:

- ориентированность на собственный внутренний мир;

- развитое воображение;

- скованность, замкнутость;

- необходимость иметь личное пространство и всячески оберегать его;

- склонность к рефлексии и самокритике.

Давайте рассмотрим перечисленные особенности в свете получения образования, чтобы понять, насколько эти черты помогают или мешают интроверту приобретать новые знания.

Внутренний мир, процессы, происходящие глубоко внутри, невероятно волнуют типичного интроверта. С одной стороны, это может привести к излишней мнительности, нервозности, неуверенности в себе. С другой стороны, склонные к самокопанию люди стремятся добраться до сути проблемы, они не удовлетворяются поверхностными знаниями. Такие люди, как правило, усидчивы и готовы потратить больше времени на то, чтобы основательно разобраться в предмете. 
Их не пугают большие и сложные задания, таким ученикам важен и интересен процесс получения новых знаний и навыков. Интроверты часто способны лучше концентрироваться на чем-то одном, им легче долгое время оставаться сосредоточенным на одном задании, не отвлекаясь, поэтому они склонны доводить начатое до конца, постоянно совершенствовать свои знания. Склонность к самокритике способствует стремлению повышать уровень полученных знаний, а не просто довольствоваться достигнутым. Кроме того, ученики-интроверты способны обучаться самостоятельно, а не только в присутствии учителя. Это является дополнительным плюсом, так как позволяет закреплять пройденный материал, доводить его до совершенства в спокойной и привычной для интроверта атмоcфepe.

Интровертивные личности нередко имеют неожиданно богатое воображение, их мысли могут поражать глубиной и последовательностью. Проблема в том, что они не показывают эту глубину. Окружающие могут даже не догадываться, что «на уме» у интроверта. Он по большей части молчит, редко высказывает свою точку зрения, если его об этом напрямую не просят. Такой человек вызывает подозрение и даже может оттолкнуть от себя, так как кажется странным, сильно отличающимся от других людей, непонятным. И преподавателю или учителю приходится приложить немало усилий, чтобы «разговорить» такого замкнутого ученика, расположить его к себе, заслужить его доверие, дать понять, что он находится в безопасной обстановке и может смело выражать свое мнение, даже если оно кардинально отличается от мнения других.

Интроверту часто сложно устанавливать контакты с другими людьми, в том числе с одноклассниками, однокурсниками, педагогами. Однако общительность не является ключевым качеством для успешного изучения того или иного предмета. Экстраверты, в отличие от интровертов, склонны быстро схватывать новый материал, но делают они это поверхностно. Они привыкли к тому, что учеба дается им чаще всего легче, и не склонны сильно напрягаться ради достижения лучшего результата. В то время как замкнутые и молчаливые интроверты более 
целеустремленные, они готовы взять ответственность за результат своего обучения, прилагать дополнительные усилия, что непременно скажется на качестве получаемого образования.

\section{Список литературы}

1. Кавасаки Г. Правила Кавасаки. - М.: Манн, Иванов и Фербер, 2015.

2. Гладуэл М. Гении и аутсайдеры. - М.: Манн, Иванов и Фербер, 2014.

3. Дэвид С. Эмоциональная гибкость. - М.: Манн, Иванов и Фербер, 2017.

4. Романцева Е. Интроверт в экстравертном мире. - СПб.: Вектор, 2013.

5. Хорни К. Невротическая личность нашего времени. - М.: Академический Проект, 2009.

6. Юнг К.Г. Психологические типы. - СПб.: Азбука, 2001. 